\title{
Ambiente escolar e paisagens simbólicas: Um estudo a partir dos vestígios encontrados no cotidiano escolar de uma escola pública de Campinas/SP
}

\section{Felipe José Carlini (IC)}

\section{Resumo}

A pesquisa aqui apresentada trata-se de uma investigação dos conceitos de paisagem e microterritorialidade, fundamentada na geografia cultural, tendo como objeto empírico as mediações simbólicas estabelecida no ambiente escolar, considerando os alunos, professores e funcionários como produtores e produtos dessa paisagem.

Palavras Chave: Paisagem, Geografia Cultural, Microterritorialidades

\section{Introducão}

Enquanto pesquisa qualitativa do Programa Institucional de Bolsa de Iniciação à Docência - PIBID da CAPES (Subprojeto Geografia - UNICAMP) a pesquisa aqui apresentada surge das ideias e reflexões realizadas a partir da experiência das observações e vivências nas escolas acompanhadas pelo subprojeto supracitado.

Segundo Kowaltowski (2011), o ambiente físico escolar é, por essência, o local do desenvolvimento do processo de ensino e aprendizagem. Nele se dão as práticas, o ensino, o cotidiano da escola. Muitos autores, nesse sentido, desenvolveram trabalhos sobre arquitetura escolar, assumindo essa como elemento importante do currículo, embora o seja, muitas vezes, conforme Frago e Escolano (2001), um elemento invisível ou silencioso, portanto, considerado como conteúdo do currículo oculto (APPLE, M. 1982). No campo da Geografia, a escola, enquanto unidade espacial, tem recebida pouca atenção pelos pesquisadores.

Cabe, então, averiguar as relações estabelecidas entre o ambiente, ou seja, as materialidades do local e as significâncias que dali emanam e como são mediadas e produzidas pelos sujeitos que ali convivem, averiguando as nuances dessa relação. Para tanto, é necessário compreender os indivíduos, o local e seus respectivos contextos na tentativa de assimilar as representações que o grupo faz do ambiente e, por conseguinte, inferir as marcas e os discursos da paisagem nas relações simbólicas.

\section{Resultados e Discussão}

Ao considerarmos 0 ambiente escolar como uma paisagem simbólica não nos interessa estudar exclusivamente o prédio em si enquanto um projeto arquitetônico, mas as representações simbólicas e os discursos explícitos e implícitos de sua paisagem e como essa paisagem revela também processos de produção de microterritorialidades internas, considerando as disposições e arranjos dos objetos e das materialidades pedagógicas, dos elementos paisagísticos, do próprio projeto arquitetônico, além de elementos como a limpeza, a sonoridade, os movimentos e ações dos sujeitos escolares.
A pesquisa insere-se na metodologia da pesquisa etnográfica, do tipo observação participativa (BOGDAN e BIKLEN. 1999). Além das observações participativas, das inserções no cotidiano escolar, da produção de um banco de imagens, também estamos aplicando entrevistas semiestruturadas junto aos sujeitos escolares. Mesmo parcialmente, temos percebido que a escola pode ser compreendida como uma paisagem simbólica considerando que o arranjo de seus objetos pedagógicos apresentam sentidos outros que o do mero ensinar-aprender de conteúdos escolares, inculcando discursos do conformismo, da alienação e passividade diante dos fatos e contextos vivenciados naquele ambiente, produzindo assim um currículo oculto (APPLE, 1982) impresso na sua paisagem. No entanto, nesse mesmo ambiente, podemos também identificar outros arranjos de subversão, como cartazes de protestos, pichações nos banheiros, sonoridades subversivas, entre outros. Nesse sentido, por mais que a paisagem escolar possa parecer homogênea e reveladora de um discurso hegemônico, identificamos que se trata de uma paisagem reveladora de discursos antagônicos, produzidas em ações de microterritorialização.

\section{Conclusões}

A pesquisa, quando finalizada, permitirá inferir e contribuir nas considerações a cerca das mediações simbólicas entre ambiente escolar e alunos, professores e funcionários a partir da ótica da geografia cultural.

\section{Agradecimentos}

Aaradeco ao Professor Dr. Rafael Straforini, pela orientação e à CAPES, pela concessão da bolsa PIBID.

APPLE, Michael W. Ideologia e currículo. São Paulo: Brasiliense, 1982.

BOGDAN, Robert C.; BIKLEN, Sari Knopp. Investigação qualitativa em educação: Uma introdução à teoria e aos métodos. Portugal: Porto editora, 1999

COSTA, Benhur Pinós da. Por uma Geografia do cotidiano: território, cultura e homoerotismo na cidade. 2008. Tese (Doutdo em Geografia) - P. Pós-graduação em Geografia, UFRGS, Porto Alegre. FRAGO, Antonio Viñao; ESCOLANO, Agustín. Curriculo, espaço e subjetividade: a arquitetura como programa. Rio de Janeiro: DP\&A, 2001.

KOWALTOWSKI, Doris C. C. K. Arquitetura escolar: o projeto do ambiente de ensino. São paulo: Oficina de textos, 2011 